\title{
Stirring Words, Ruling Ideas, and the Price of
}

\section{Bread:}

\section{Reflections on a Gramscian-Thompsonian}

\author{
Approach \\ to Cultural History \\ Peter Rogers
}

This paper undertakes to examine and criticize one or no amahtical categories which have acquired currency among historians and social scientists working wirhin a paradigm that derives, broadly speaking. from Marx. Specificall!: I shall be concerned with questions of consciousness, agency; and determination: with the extent to which a "popular" culture can be distinguished from a "dominam" one; with the kinds of intercourse that may or may not occur benteen the nio: and with the more general interplay between cultural processes and political and economic ones, out of which, it will be argued. emerge such quotidian facts as the price of bread. Still more specificall!: I wish 10 consider the pertinence of the notions of "hegemonn." and "the moral econom! of the poor." as elaborated in the work of Antonio Gramsci and Edward Thompson, respectivel!: in investigating these matters.

Those who would write the history of culture are apt to disdain the legacy of Marx, if only to distinguish themselves from the social historians of an earlier decade. This in itself is nothing remarkable. All things flow: and fields of scholarship are no exception to the Heraclitean rule. In any case. a diehard historical-materialist may. with reasonable assurance. expect a tide which has gone out to come in again. What is worth noting is that the postmodernist tum has not. in fact. left every category of Marxian analysis high and dry. Two in particular remain surprisingly au couram: I refer to the notions of "hegemony" and "moral economy" as expounded by Antonio Gramsci and Edward Thompson. respectively.

This paper argues that the continued attention paid to these wo authors is well deserved, but that their ideas. cut loose. with or without ceremony. from the tradition that nourished them. have been seriously misconstrued. Indeed. there can be no legitimate traffic in the disembedded elements of dialectical thought however brisk the demand. for they are fraudulent by definition. The result is never sorrier than when the two elements in question. 10 wit. the concepts of hegemony and moral economy, having been serially decontextualized. are then 
brought together and interpreted as the terms of a binary opposition. In such commentaries. a few of which 1 shall cite momentarily, two straw men are made to confront one another in a zero-sum game: most of the time, the dummy in the Gramscian jersey allows the rich and powerful to exercise their cultural hegemony: just occasionally, the dummy in the Thompsonian jersey intervenes and lets the poor and downtrodden assert their moral economy. A duller. more pointless contest is difficult to imagine.

I shall counter this sterile antithesis by interpreting hegemony and moral economy not as polar opposites but as the internally related components of a dy namic sy'stem. In other words, the "dominant" and the "popular" cultures resemble more closely the magnetic than the geodetic poles: they are inextricably linked by a "ficld of force." to use one of Thompson's metaphors, whose effects are felt across the entire sphere defined by their interaction and include. as we shall see. such quotidian facts as the price of bread.

To recuperate and rehabilitate the ideas of Gramsci and Thompson seems to me an undertaking that needs no apology. Yet in today's noisily postMarxist milieu it may well strike the reader as an exercise in nostalgia; and I shall therefore begin by addressing her predictable sense of dejà vu. The star of Marxist historiography is widely supposed, at least in the English-speaking world, to have risen in the 1960s. ${ }^{1}$ reacled its apogee in the mid-1970s, and finallyindeed. definitively-vanished beneath the historical horizon established by the events of 1989-1991. In the present conjuncture, demarcated in economic and geopolitical terms by the closure of the last significant gaps in the capitalist world-system. and intellectually by the noisy counterposition of neoliberal triumphalism and posimodernist pessimism, Marxism is understandably viewed as a horse that no longer merits flogging. any danger of its resuscitation now being comfortably remote. Indeed, there are those who have already turned their attention to the exorcism of its ghost. ${ }^{2}$

The beast that is being laid to rest, however, deserves to have the proper name engraved on its tombstone: not historical materialism, but its vulgar caricature, that "global, totalitarian theony;" as Michel Foucault once labeled it

\footnotetext{
'The faultiness of this perception. even as regards British historiography, is exposed by Raphael Samuel. See Raphael Samuel, "Britis) Marxist Historians, 1880-1980 (Part One)." New Lefi Review 120 (1980).

'See Jacques Derrida. "Spectres of Marx," New' Left Review' 205 (1994). It is worth noting. however. that Derrida finds himself haumted by not one, but several of Marx's "spirits" and proposes to cast off the baleful influence of some but not all of them (32-33); this lecture appeared in expanded form in Jacques Derrida. Spectres of Marx: The State of the Debt. the Work of Mourning, and the New International. trans. Peggy Kamuf (London: Routledge. 1994).
} 
with notable. if unconscious aptness. ${ }^{3}$ This theory purported to explain anything and everything by reference to a jerry-built apparatus of formulae. models. and tropes, lifted out of context from the sacred canon of Soviet scholasticism and passed off for several generations as the genuine article by virtue of a worldgirdling, universal discourse, which Cold Warriors on both sides of the putative ideological divide mutually embraced. As Raphael Samuel notes. if fundamentalists have been anxious "to reaffirm the consistency of Marxism" and to represent it as a "closed system," anti-Marxists "are even more concerned to prove that Marxism is a totality, and will ransack the obscurest texts to demonstrate its monolithic character. ${ }^{-4}$

To appreciate the patent absurdity of such efforts. it should suffice to recall the radically unfinished character of Marx's own intellectual project. Of the six books that were to have comprised his "critique of political economy." completed only the first volume of Book One. leaving rough drafts of the second and third volumes and no more than a few sketchy allusions as to the proposed contents of the remaining five books. This circumstance is all the more striking when we observe that the method employed in Capital is that of " 'successive approximations,' which attempts to move step-by-step from the more abstract. pure forms of a phenomenon to its more concrete forms. by gradually relaxing simplifying assumptions in order to embrace an ever larger reality." "It follows that Marx's central theoretical text. even if we accept it on his own terms. offers no more than a first approximation of an analytical framework appropriate to the interpretation of modern history. Significantly. it was not Georg Lukacs. but Frederick Engels who wrote. "his way of viewing things is not a doctrine but a method. It does not provide ready-made dogmas. but criteria for further research." ${ }^{7}$ Hence Engels's remarkable comment. recorded many years after Marx's death and shortly before his own. that the task of providing the materialist conception of history with a substantive content had scarcely begun. As understood by its founders, then, historical materialism is not a "global theory" which closes off further inquiry but a method which initiates it: a research

\footnotetext{
3Michel Foucault, "Two Lectures." in Culsure/Power'Histon?: A Reader in Comemporan. Social Theory. eds. Nicholas B. Dirks. Geofr Eley, and Sherry B. Ortner (Princeton: Princeton University Press, 1994), 202, emphasis in original: Foucault. of course. applied the phrase to Marxisin per se. without the qualification stipulated here.

tSamuel,"British Marxist Historians." 21.

3.-The whole business is to be divided into six books: 1) Capital. 2) Landed Property. 3) Wage Labour. 4) State. 5) Intemational Trade. 6) World Market": Mar. letter to Engels. 2 April 1858. in Karl Marx and Frederick Engels. Selected Correspondence. Irans. I. Lasker. 3rd ed. (Moscow: Progress Publishers. 1975). 97.

'John Bellamy Foster. Introduction to Joseph Ferraro. Freedom and Determination in Historn' According to Marx ased Engels (New York: Monthly Review Press. 1992). 19.

'Letter to Sombart. 11 March 1895, in Marx and Engels. Selected Correspondence. 455.
} 
program which problematizes history by positing previously unrecognized interconnections between social, economic. political, cultural, and intellectual processes. thereby opening an entire "new continent" (to appropriate Louis Althusser's apt expression. albeit not quite in the sense he intended) of social reality to theoretical and empirical investigation. Nor can this new continent be explored without continually developing, expanding, and even refashioning the conceptual tool-kit-that tentative, unfinished, initial approximation-which Marx bequeathed. As Perry Anderson observes: "To take "liberties' with the signature of Marx is in this sense ... not to depart from historical materialism but to rejoin is. ${ }^{.8}$

During the century since Engels's death, creative Marxists like V. I. Lenin. Antonio Gramsci. and E. P. Thompson have repeatedly taken such liberties: and they have done so. of course, in response to altered circumstances of which the founders of the paradigm had nothing to say. "So far from being immunc to exogamous influences," writes Samuel, "Marxism may rather be seen-in the light of its history-as a palimpsest on which they are inscribed."

That said. I now turn to the decipherment and analysis of two of these inscriptions which bear the handwriting of Lenin and Gramsci, on the one hand, and of Thompson. on the other: hegemony and moral economy. ${ }^{10}$ My argument,

${ }^{8}$ Perny Anderson. Passuges from timiquin to Feudalism (London: Verso, 1974), 9.

"Samuel. "British Marist Historians." 24.

${ }^{10}$ Regrettably. space is lacking is which to provide a properly detailed exegesis-much less an intellectual history of the derivation. definitive statement. and subsequent use or misuse-of either concept. I therefore touch only on those points which are essential to the present discussion. and assume a reader who is sufficiently familiar with the relevant literature as to accommodate the unglossed introduction of such terms as "organic intellectuals." "historic bloc." or "the paternalist model." for example. While hegemony was widely discussed by Russian Marxists from Plekhanov onwards. most notably by Lenin. and figured in the discourse of the Communist International, the locus classicus of its contemporany usage is of course Antonio Gramsci. Selections from the Prison Norebooks. trans. Quintin Hoare and Geoffrey Nowell Smith (New York: Intemational Publishers. 1971). Unfortunately, owing to the inauspicious conditions under which it was written-confinement under close surveillance in a Fascist jail-this text makes for notoriously difficult reading. Unpolished. fragmentary, disorganized, forbiddingly abstract. its locutions are often also vague. ambiguous, or elliptical. For an admirably lucid. critical exposition of the main ideas, see Perry Anderson. "The Antinomies of Antonio Gramsci." Nell Lefi Reviell 100 (1976-1977): 5-78; see also Terry Eagleton. Ideology: An Introduction (New York: Verso. 1991). 112 ff. In contrast to Gramsci's Notebooks. the article in which E. P. Thompson introduced the notion of moral economy into modem historiography: E. P. Thompson. "The Moral Economy of the English Crowd in the Eighteentl Century:" in Customs in Common (New York: New Press. 1993), provides a luminous example. not only of the graceful integration of conceptual analysis and empirical research. but of the author's justly celebrated mastery of English prose. For 
expressed in terms of Samuel's felicitous metaphor. will be that Thompson's contribution to the palimpsest is inscribed upon Gramsci's. which it helps to complete and to elucidate. This is not commonly perceived as being the case. In fact, a considerable body of literature has arisen which interprets the two categories as mutually exclusive. According to these latter-day inscriptions. the moral economy of the poor betokens the autonomous and potentially rebellious character of popular culture, whereas hegemony indicates precisely the reverse. the heteronomy of plebeian consciousness. the cultural subordination of the masses by political or economic elites. In order to reach the level at which Gramsci and Thompson were working. therefore. we must begin by removing some of the graffiti which have accumulated on top of it. that is. by controverting the argument that hegemony and moral economy comprise the terms of an antithesis.

Likely the most prominent expositor of this position has been James $C$. Scott. In a 1977 article. which it will be useful to cite at some length. he advanced the view that. contrary to the expectations of classical Marxism. the peasantry in the Third World had shown itself in the iwentieth century to be a more revolutionary class than the proletariat in the industrialized countries. This he ascribed to the following circumstances:

The relative isolation of the peasantry from the cultural and institutional life of the state and its ruling elites has meant that. as a class, it has been more immune than has the proletarial to the social and moral hegemony (in the sense in which Gramsci used that word) of the dominant classes. ...

The seemingly archaic. precapitalist moral economy of the peasantry, it may be argued. also constitutes a decisive advantage for the revolutionary potential of the peasantry....

Much of the rural resistance to hegemonic institutions among peasants derives from the fact that the peasantry is an

interpretation and criticism see James C. Scott. The Moral Econom! of the Peasant: Rebellion and Subsistence in Southeast Asia (New Haven: Yale University Press. 1976): A. Charlesworth and Adrian Randall. "Comment: Morals. Markets and the English Crowd in 1766." Past and Present 114 (1987): 200-213: Elizabeth Fox-Genovese. "The Many Faces of Moral Economy." Past and Presem 58 (1973): 161-168: A. W. Coats. "Contrary Moralities: Plebs. Patemalists and Political Economists." Past and Presem \$4 (1972): 130133: J. Stevenson. "The "Moral Economy" of the English Crowd: Myth and Reality." in Order and Disorder in Early Modern England. ed. Anthony Fletcher and J. Stevenson (Cambridge: Cambridge University Press. 1985): and Dale E. Williams. "Morals. Markets and the English Crowd in 1766." Past and Presem 104 (1984): 56-73. For Thompson's response to his critics see E. P. Thompson. "The Moral Economy Reviewed." in Customs in Common (New York: New Press. 1993). 
old. precapitalist class. Social relations within the typical village are the artifacts of custom, oral tradition, and a dense network of personal relations. The rule of custom orders behavior in accordance with local standards without regard for its standing in law. The effect of an oral tradition is to reduce the impact of newspapers and the written texts of what is known as the "great tradition" on the practitioners of "little traditions"...

There are thus good reasons for suspecting that the institutions promoting hegemony are less thick on the ground among the peasantry than among the proletariat. ...

The radical potential of the peasantry lies not only in their isolated and communal social organization but, above all, in their normative culture, which ... is frequently antithetical to the values of hegemonic institutions. This antithesis may be seen in the realm of what I have chosen to call the moral economy of the peasantry ..."

It is important to take note of what Scott understands by "hegemony," or more precisely. what he represents Gramsci as having understood by the word:

Gramsci sees [hegemony] as the product of the symbolic reach of dominant classes that prevents subordinate classes from thinking and acling on the basis of their objective interests.

Just as dominant classes control the means of physical production. Gramsci argues. so do they control the means of symbolic production. Their domination of the material forces of production is thus replicated, at the level of ideas, in their domination of the "ideological" sectors of society-culture. religion. education. and media-in a manner that allows them to disseminate those values that reinforce their position. By creating a universe of discourse and the concepts accompanying it. by defining the standards of what is true, beautiful, moral, and legitimate. they create a mystifying symbolic climate that makes proletarian class-consciousness difficult if not impossible. What Gramsci has done, in brief, is to explain the institutional basis of "false consciousness."12

\footnotetext{
"James C. Scoll. "Hegemony and the Peasantry." Politics and Socieṇ. 7:3 (1977): 270278. emphasis in original: see also Scott. Moral Econom! of the Peasant .

"Scott. "Hegemony and the Peasantry." 271-272.
} 
Thus. Scott equates hegemony with ideological domination. achieved through the promulgation of mystifying discourses that promote a false consciousness on the part of the dominated and claims that this is "the sense in which Gramsci used that word." The merits of this claim will be evaluated presently. First. however. a few remarks on the subsequent evolution of the dualistic model may be in order.

Initially, as we have seen. Scott viewed each of the terms of his theoretical dichotomy as having its valid sphere of application. provided one took due care to ensure that neither was allowed to stray from its appropriate geographical and sociological domain, to wit. that hegemony was relegated to the cities with the proletariat. moral economy to the countryside with the peasantry. In more recent work, however, he has preferred to discard the notion of hegemony altogether, as being empirically untenable. since it cannot account for social instability: "The problem with the hegemonic thesis. at least in its strong forms as proposed by some of Gramsci's successors"-among them. as we have just seen. a certain James Scott-"is that it is difficult to explain how social change could ever originate from below. If elites ... control the means of symbolic production, thereby ensuring that their power and control are legitimized. one has achieved a self-perpetuating equilibrium that can be disturbed only by an external shock. ${ }^{13}$

In his anxiety to avoid the Scylla of an unshakable. rock-solid equilibrium, however. Scott has apparently fallen into the Charybdis of perpetual turbidity. As Alan Knight observes, he "seems to posit a standard condition of peasant discontent and potential subversion in agrarian societies. ${ }^{-1+}$ That is to say. if in Scott's rendition the idea of hegemony fails to account for resistance. rebellion. and revolution, then his preferred categories of moral economy and the "weapons of the weak" fail to account for periods of comparative quiescence. Knight, for his part, while accepting the terms of the antithesis Scott poses. as well as his definition of hegemony. opts for dualism: "In my view: the notion of hegemony (or its various alternatives: mystification, ideological domination. false consciousness) should be used cautiously and sparingly ... But in certain circumstances hegemony, or something like it. seems to fit the historical pattern. just as the 'moral economy' or the 'weapons of the weak' seem to fit elsewhere." ${ }^{-15}$

\footnotetext{
${ }^{13}$ James C. Scott. Domination and the Arts of Resistance: Hidden Transcripts (New Haven: Yale University Press. 1990). p. 78: see also James C. Scott. Weapons of the I'eak: Evernday Forms of Peasamt Resistance (New Haven: Yale University Press. 1985). chap. 8.

${ }^{14}$ Alan Knight. "Weapons and Arches in the Mexican Revolutionary Landscape." in Evenday, Forms of State Formation: Revolution and the Negotiation of Rule in Modern Mexico. eds. Gilbert M. Joseph and Daniel Nugent (Durliam: Duke University Press. 1994). 43.

${ }^{15}$ Ibid. $42-43$.
} 
Before abandoning our survey of dualistic constructions, let us examine one final such formulation. that of Suzanne Desan, which conveniently allows us to bring E. P. Thompson into the picture:

Thompson ... thinks that Gramsci overestimated the capacity of
the elites to impose "cultural hegemony" on the masses and
underestimated the resilient ability of the lower classes to limit
and reformulate these cultural impositions. Specifically,
Thompson claims that patricians and plebeians had a reciprocal
relationship in the eighteenth century. The gentry used a vast
repertoire of theatrical and symbolic means to assert its
paternalist control and to exact deference and obedience from
the crowd. but the plebeians clung to their autonomous,
traditional popular culture. which enabled them to resist.
redefine. and limit the hegemony of the gentry.

Thus, even while emphasizing the reciprocity involved in inter-class relations, Desan concurs with Scott and Knight in construing Thompson's inscription not as a gloss upon Gramsci 's but as an alternative to it, a necessary corrective to a onesided approach. if not indeed an outright rejection of that approach. All three authors conceive of elite and popular cultures in an atomistic fashion, as if the relations between the two were purely external. Insofar as these distinct entities are permitted to interact. they must evidently observe the protocols of a zero-sum game. wherein any increase in the hegemony of the gentry coincides with a decrease in the moral economy of the poor, and vice versa. This stark dichotomy is conjured up. however. only by oversimplifying the views of both Gramsci and Thompson to the point of serious misrepresentation, as I shall now endeavor to demonstrate.

Did Gramsci believe. as Desan has him doing, in "the capacity of the elites to impose "cultural hegemony" on the masses"? Did he understand by hegemony. as Scott maintains he did. "the symbolic reach of dominant classes that prevents subordinate classes from thinking and acting on the basis of their objective interests"? Did he. like Knight, equate it with "mystification, idcological domination. false consciousness"? Quite the contrary. One might go so far as to say that Gramsci. along with Thompson, effectively subscribed to the

\footnotetext{
${ }^{10}$ Suzanne Desan. "Crowds. Community, and Ritual in the Work of E. P. Thompson and Natalie Davis." in The Nell Cultural History, ed. Lynn Hunt (Berkeley: University of Califormia Press. 1989). 60. Since I will shortly be contesting this interpretation. it is only fair to note that it appeared before Thompson had published E. P. Thompson. Customs in Common (New York: New Press. 1993). which contains the formulations. cited below in the text. that expressly contradict it.
} 
maxim of a certain quintessential Yankee who said. "you can't lool all of the people all of the time." They both argued that human consciousness is not indefinitely malleable: that people are somewhat perceptive and somewhat rational: and that, therefore. they are in the long run capable of apprehending discrepancies between the situations they actually experience and the representations of those situations which are advanced by others with a view to their social edification. Thus Thompson: "I cannot accept the view. popular in some structuralist and Marxist circles in Westem Europe. that hegemony imposes an all-embracing domination upon the ruled ... reaching down to the very threshold of their experience, and implanting within their minds at birth categories of subordination which they are powerless to shed and which their experience is powerless to correct. ${ }^{-17}$ And thus Gramsci: "the peasants. having mulled for a long time the assertions that they have heard proclaimed and whose glitter has temporarily dazzled them, end up, when good sense wins over the emotions aroused by stirring words. by discovering their inadequacy and superficiality and become generally distrustful. ${ }^{* 18}$

As with Lenin in the case of Russia. Gramsci applied to Italy the strategic perspective that a socialist revolution was possible only on the condition that the proletariat could "lead" the peasantry into a new "historic bloc." thereby asserting its own hegemony in place of that of the bourgeoisie. This did not mean that the working class. via its organic intellectuals. would "impose" proletarian ideas upon the peasants, however. Rather, "the starting point must alway's be that common sense which is the spontaneous philosophy of the multitude and which has to be made ideologically coherent. ${ }^{" 19}$ The role of the organic intellectuals. then. would be to articulate and give form to the ideas of the peasants themselves. whether these were implicit in the peasant's actions or embodied in their popular (or as Gramsci put it, folkloric) culture:

It would be necessary to study [folklore] ... as "a view of the world and life" to a great extent implicit. of determinate strata (determinate in space and time) of the society. counterposed ... to the "official" views of the world (or in a wider sense of the historically educated determinate parts of society ... Thus the close link between folklore and popular wisdom [senso comme]. which is folkloric philosophy). A view of the world which is not only not systematic and elaborated because the people ... by definition cannot have systematic. elaborate and politically organised and centralised conceptions even in

\footnotetext{
17Thompson. Customs in Common. 87.

${ }^{13}$ Gramsci. cited in Alastair Davidson. "Gramsci. the Peasantry. and Popular Culture." Journal of Peasant Studies 11:4 (1984): 147.

${ }^{10} \mathrm{Gramsci}$. Selections from Prison Notebooks, 421.
} 
contradictory development, but, indeed, multiple - not only in the sense of diverse and juxtaposed, but also in the sense of stratified from the least to the most vulgar-if, indeed, it is not a malter of having to speak of an undigested heaping-up of fragments of all the views of the world and of life which have followed one another throughout history ...20

Such a diverse and fragmented culture would doubtless include conservative elements. but it would also encompass "a series of innovations, often creative and progressive. spontaneously determined by the forms and conditions of life in the process of development and which are in contradiction, or just different, from the morality of the ruling strata. ${ }^{.21}$ Only by taking up these progressive elements of peasant culture. by elaborating them and expressing them more coherently than was possible for the peasants themselves given their conditions of life, could proletarian militants hope to bring the peasantry into a new hegemonic order."2

We have already come a long distance, it seems, from Scott's rendition of hegemony. whereby "dominant classes ... control the means of symbolic production" and are thereby enabled "to disseminate those values that reinforce their position." But if such a mechanistic model cannot properly be ascribed to Gramsci. can it not perhaps be discerned beneath his own handwriting? Is this not the import of the original or foundational layer of the Marxist palimpsest, the message recorded on the virgin parchment itself? It is, after all, in the German Ideology that we read:

The ideas of the ruling class are in every epoch the ruling ideas, i.e.. the class which is the ruling material force of society, is at the same time its ruling intellectural force. The class which has the means of material production at its disposal, has control at the same time over the means of mental production, so that thereby: generally speaking. the ideas of those who lack the means of mental production are subject to it. ... The individuals of the ruling class possess among other things consciousness.

\footnotetext{
${ }^{20}$ Gramsci. cited in Davidson. 1+6-147.

"II Ibid.. 147.

2-It is intriguing to note the close parallel between this project, sketched by Gramsci during his imprisonment. and that developed a few years earlier by the Peruvian Marxist José Carlos Mariategui with respect to the indigenous campesinos of the Andean sierra: see José Carlos Mariátegui. Ideología I' Politica, vol. 13 of Obras Completas (Lima: Empresa Editora Amaula. 1969): Thomas Angotti. "The Contributions of José Carlos Mariátegui to Revolutionan Theory:" Latin American Perspectives 13:2 (1986): Alberto Flores Galindo. La Agonia De .Murviátegui: La Polémica Con La Komintern (Lima: Centro de Estudios y Promoción del Desarrollo. 1980).
} 
and therefore think. Insofar, therefore. as they rule as a class and determine the extent and compass of an epoch. it is selfevident that they do this in its whole range. hence among other things rule also as thinkers, as producers of ideas. and regulate the production and distribution of the ideas of their age ....3

If one were to read thus far and no further, one might indeed come away with a rather mechanistic view of the relation between "social being" and "social consciousness." Nonetheless, even this very abstract formulation should not to be discarded too hastily. By specifying some of the material conditions under which consciousness is produced and disseminated, Marx and Engels here take the first. crucial steps toward fashioning the indispensable rudiments of any serious sociology of knowledge. At this stage the account remains crude. schematic. algebraic: yet one has only to read a book like Edward S. Herman and Noam Chomsky's Mamufacturing Consent to appreciate the continuing force and relevance of the points it does make. ${ }^{24}$ Privileged access to the means of intellectual production is surely a vital element in the constitution of hegemonic regimes. Yet. as Gramsci's observations concerning "folklore" suggest. it is not in itself a sufficient condition. One cannot understand hegemony by taking account only of the immediate social provenance of the ruling ideas, nor even of the human agency and the material or institutional mechanisms involved in their transmission. It is equally essential to attend to the content of these ideas: for unless this content is appropriate, unless they happen to be the right ideas with respect to the time and place, the social context and the political conjuncture in which hegemony is to be established. they can never become the ruling ideas. But to discover all this we need not have tumed to Gramsci. We need only turn the page of The German Ideologi:

If now in considering the course of history we detach the ideas of the ruling class from the ruling class itself and attribute to them an independent existence. if we confine ourselves to saying that these or those ideas were dominant at a given time. without bothering ourselves about the conditions of production and the producers of these ideas. if we thus ignore the individuals and world conditions which are the source of the ideas. we can say, for instance. that during the time that the aristocracy was dominant. the concepts honour. loyalty. etc. . were dominant. during the dominance of the bourgeoisie the

\footnotetext{
${ }^{23}$ Karl Marx and Frederick Engels. The German Ideologn (New York: Intenational Publishers. 1970), 64-65.

${ }^{24}$ Edward S. Herman and Noam Chomsky. Mamufacturing Consent: The Political Econom! of the Mass Media (New York: Pantheon Books. 1988).
} 
concepts of freedom, equality, etc. The ruling class on the whole imagines this to be so. This conception of history, which is common to all historians, particularly since the eighteenth century: will necessarily come up against the phenomenon that increasingly abstract ideas hold sway, i.e., ideas which increasingly take on the form of universality. For each new class which puts itself in the place of one ruling before it, is compelled. merely in order to carry through its aim, to represent its interest as the common interest of all members of society, that is. expressed in ideal form: it has to give its ideas the form of universality. and represent them as the only rational, universally valid ones. ${ }^{25}$

Of course, if one were to investigate the consciousness of a ruling class empirically. by examining the recorded thoughts of its individual members, one would discover forthwith that these only rarely and exceptionally possess "the form of universality." More often they are concerned with narrow, selfish, particular interests. Only infrequently does one come across individuals who articulate ideas capable of being universalized, ideas which have a trans-corporate or Irans-class appeal. Rare as they are, however, such individuals can play a disproportionate role in history since they constitute the natural or "organic" leadership of the class in question. or in Eugene Genovese's words, "the most advanced fraction of the [class] - those who most clearly perceive ... the interests and needs of the class as a whole-[those who] steadily work ... to make their class more conscious of its nature, spirit, and destiny." ${ }^{26}$ Much as, in Darwinian biology. random variations are "naturally selected" when they contribute to the survival or reproductive success of organisms, and thereby partake in the evolution of species. Whereas non-adaptive variations are of no evolutionary consequence. so the universal ideas of the organic intellectuals are selected historically when they facilitate the construction of a hegemonic order, and thereby impart momentum to the historical development of a new social formation.

Gramsci posited just such a process of "selection" in interpreting the course of events during the French Revolution. In 1789, he observes, the bourgeoisic was merely an especially vocal faction of the Third Estate, a heterogenous group which "had a very disparate intellectual élite":

\footnotetext{
${ }^{25}$ Marx and Engels. German Kleologi. 65-66.

${ }^{26}$ Eugene D. Genovese. Roll. Jordan. Roll: The W'orld the Slaves Made (New York: Vinlage Books. 1974). 27.
} 
Events developed along highly interesting lines. The representatives of the Third Estate initially only posed those questions which interested the actual physical members of the social group. their immediate "corporate" interests (corporate in the traditional sense, of the immediate and narrowly selfish interests of a particular category). ... Gradually a new élite was selected which did not concern itself solely with "corporate" reforms. but tended to conceive of the bourgeoisie as the hegemonic group of all the popular forces. ... The Jacobins ... not only represented the immediate needs and aspirations of the actual physical individuals who constituted the French bourgeoisie, but they also represented the revolutionary movement as a whole. as an integral historical development. For they represented future needs as well, and. once again. not only the needs of those particular physical individuals. but also of all the national groups which had to be assimilated to the existing fundamental group. ... They were convinced of the absolute truth of their slogans about equality. fraternity and liberty, and, what is more important, the great popular masses whom the Jacobins stirred up and drew into the struggle were also convinced of their truth.7

But what is the source of this conviction? Recalling Gramsci's references to the subaltern masses" "popular wisdom," their capacity to become disillusioned with "stirring words" that fail to address their concerns in an adequate manner. it is evident that an explanation couched in terms of technocracy-" control of the means of symbolic production"-will not suffice. While a ruling elite may indeed have the capacity (by virtue of controlling the requisitc apparatuses of administration, surveillance, and law enforcement. for example) to impose "its own" ideology on a skeptical populace-the very fate. one need scarcely add. which befell official "Marxism-Leninism" in the Soviet Union-what is achieved thereby is merely a gnudging lip service. elicited by virtue of "direct domination" rather than "hegemony." Insofar as a political regime relies on direct domination. that is to say, the ideas of the rulers are constituted as the ruling ideas merely because the rulers happen to rule, then Marx and Engels's famous aphorism is reduced to an empty tautology. To the extent that the order is a hegemonic one. on the other hand. the rulers are enabled to rule through the efficacy of the ruling ideas which they expound; and these ideas in turn derive their power from the universal (or universalizable) "common sense" which they articulate or codify: a sense, in other words, which is "common" (the qualification which occasions the

${ }^{27}$ Gramsci, Selections from Prison Notebooks, 77-78. 
use of quolation marks will be specified in a moment) to both the rulers and the ruled-or. in any event. to all those classes, castes. or strata which are to be incorporaled into the "historic bloc" and govemed hegemonically rather than dictatorially.

But if the ruling ideas are not to be imposed on the subaltern masses through intimidation or violence; if the masses must instead be persuaded by the force of these ideas themselves, convinced of their inherent veracity, or in any case their verisimilitude: if the ruling ideas, in order to rule. must therefore express or capture or represent the social experience of the lower and not merely the upper orders: then in what sense can such ideas be defined as being specifically those of the ruling class? Are we not. as Etienne Balibar wonders, "led to the following question: which is the (imaginary) experience that can be universalized. that is both generalized and idealized in society?" His conclusion is as follows:

Contrary to the common assumption of most sociological theories of legitimacy and hegemony, it cannot be primarily the "lived" experience of the rulers, but only the "lived" experience of the dominated masses ... We reach the paradoxical thesis that in the last instance there is nothing like a dominant ideology of the rulers ... The dominant ideology in a given society is a specific universalization of the imaginary of the cominated: what it elaborates are such notions as Justice, Liberty and Equality. Effort and Happiness, etc., which draw their potential universal meaning from their belonging to the imaginary of the individuals who live the masses' or the people's conditions.

... Just as the accumulation of capital is made of "living labor" (according 10 Marx), so the oppressive apparatuses of the State. Churches, and other dominant institutions function with the popular religious, moral, legal and acsthetic imaginary of the masses as their specific fuel. ${ }^{28}$

This paradox. we should note, does not arise from any sort of intellectual hoodwinking or sleight-of-hand: the people are not content merely to witness their own "needs and aspirations" paraded before them in the fineries of high culture. They also insist on having their needs attended to, and occasionally even demand that their aspirations be fulfilled as well. In global or structural terms the

${ }^{28}$ Etienne Balibar. "The Non-Contemporaneity of Althusser," in The Althusserian Legacy. ed. E. Ann Kaplan and Michael Sprinker (London and New York: Verso, 1993). 12-13. emphasis in original. 
universality of the ruling ideas-the claim that subordinate and superordinate classes share "common" values, objectives, and interests-is no doubt an illusion. But people do not live their lives according to the rhythm of the longue dirée: and in everyday experience there may well be occasions when. as Marx once expressed himself. "this illusion is true." 29 The regular occurrence of such occasions is arguably the most vital condition on which the stability of hegemonic regimes is predicated, and we must therefore turn our attention to the manner in which they come to pass.

Heretofore, we have been considering the construction of hegemony as if it were a purely cultural affair, as if it took place wholly on the ground of consciousness or ideology. To be sure, we have taken note of the materialist stricture that consciousness itself is produced and transmitted under specific social, historical. and technical conditions: but we have not established the materiality of the ruling ideas themselves. that is. their adequacy to social experience, or truth-content. Gramsci begins to spell out the real as opposed to the ideal basis of hegemony by introducing the category of needs. He insists that the Jacobins, the organic intellectuals of the revolutionary bourgeoisie. do not merely give voice to these needs, but represent them (in what is here interpreted as a material sense of the word "represent"). Above all, he specifies that the needs so represented are not those of the emergent hegemonic class exclusively. but of the entire historic bloc which that class is in the process of assembling. ${ }^{30}$ It is not enough for the ruling class to propound the ruling ideas: it must also provide those ideas with a material content.

In other words, the notion of hegemony, "in the sense in which Gramsci used that word," cannot be reduced to the so-called "dominant ideology thesis." 31 As Terry Eagleton points out, "hegemony ... includes ideology. but is not reducible to it. A ruling group or class may secure consent to its power by ideological means: but it may also do so by, say. altering the tax system in ways favourable to groups whose support it needs. or creating a layer of relatively

\footnotetext{
${ }^{20}$ Marx and Engels, German Ideologi, 66.

${ }^{30}$ Here. once again. we may note that Gramsci's formulations have not strayed far from those of The German /deology: "The class making a revolution appears from the very start. if only because it is opposed to a class. not as a class but as the representative of the whole of society: it appears as the whole mass of society confronting the one ruling class. It can do this because, to start with. its interest really is more connected with the common interests of all other non-ruling classes ... Even new class. therefore. achieves its hegemony only on a broader basis than that of the class nuling previously": Ibid.. 66 . emphasis in original.

${ }^{31}$ Nicholas Abercrombie. Stephen Hill. and Bryan S. Tumer. The Dominam Ideolog. Thesis (London: George Allen \& Unwin. 1980).
} 
affluent. and thus somewhat politically quiescent, workers."32 Either of the latter alternatives clearly implies a compromise of material interests: hegemonic actions may indeed speak louder than words, but the consent obtained thereby is not without a cost. "Undoubtedly," writes Gramsci, "the fact of hegemony presupposes that account must be taken of the interests and the tendencies of the groups over which hegemony is to be exercised. and that a certain compromise equilibrium should be formed-in other words, that the leading group should make sacrilices of an economic-corporate kind. ${ }^{.33}$

The question remains, however: How, precisely, is such a "compromise equilibrium" arrived at on the ground? How is it accomplished, in other words, in concrete. historical circumstances? And it is here that E. P. Thompson's contribution is indispensable. For Thompson, unlike Gramsci, shows us the process in action. in all its gritty detail, with all its inherent tensions, conflicts, and ambiguities. Above all. he demonstrates that the relative stability which characterizes hegemonic systems is not to be viewed as "a self-perpetuating equilibrium that can be disturbed only by an extermal shock" (to recall Scott's characterization. cited above). but rather as a dynamic balance of forces which is continually being tested. contested. disrupted, revised, and re-established, as patricians and plebs negotiate and renegotiate the terms of their historic compromise. They do so. as we shall see, along a front of engagement that is at once economic and symbolic: a theater in which the distribution of wealth and the meaning of the ruling ideas are simultaneously determined. Far from being "antithetical" to the functioning of the hegemonic system, the moral economy of the poor is. in Thompson's usage (as opposed to Scott's), integral to it, an intrinsic element in the "symbolic contest" with its patrician contrapositive, the paternalist model. ${ }^{34}$ But there is no sense paraphrasing what Thompson states so clearly himself:

This symbolic contest acquires its significance only within a particular equilibrium of social relations. The plebeian culture cannot be analysed independently of this equilibrium; its definitions are. in some part. antitheses to the definitions of the polite culture. What I have been attempting to show, perhaps repetitiously: is that each element of this society, taken separately. may have precedents and successors, but that when all are taken together they add up to a sum which is more than the sum of the parts: it is a structured set of relations, in which the state. the law. the libertarian ideology, the ebullitions and

${ }^{32}$ Eagleton. Heologr: 112.

"Gramsci. Selections from Prison Notebooks. 161.

${ }^{34}$ Thompson accepts A. J. Randall's formulation: "the moral economy was the obverse of the patemalist model“: cited in Thompson. “Moral Economy Reviewed," 339. 
direct actions of the crowd. all perform roles intrinsic to that system, and within limits assigned by that system. which limits are at the same time the limits of what is politically "possible": and, to a remarkable degree. the limits of what is intellectually and culturally "possible" also."

In a word. "This plebeian culture is. in the end. constrained within the parameters of gentry hegemony." 36

But if Thompson does not interpret the moral economy of the poor as implying so radical an autonomy for popular culture as does Scott. neither does he interpret hegemony as implying either impenetrable mystification or irredeemable cultural subordination:

It is necessary also to say what this hegemony does not entail. It does not entail any acceptance by the poor of the gentry's paternalism upon the gentry's own terms or in their approved self-image. The poor might be willing to award their deference to the gentry, but only for a price. The price was substantial. And the deference was often without the least illusion: it could be seen from below as being one part necessary selfpreservation. one part the calculated extraction of whatever could be extracted. Seen in this way, the poor imposed upon the rich some of the duties and functions of patemalism just as much as deference was in turn imposed upon them. Both parties to the question were constrained within a common field-offorce. ${ }^{37}$

According to Thompson, then. what we need to examine are the characteristics of a dynamic system. one whose equilibrium-level is determined by a struggle. symbolic as well as material, between the patricians and the plebs. Situating this contest within the analytical framework laid out above. I will argue that it was played out over conflicting interpretations of an ideology they shared in "common": the ruling ideas of their epocl..

What was that hegemonic ideology? Its nature can best be appreciated with reference to the historical context (even if. for reasons of space. only the barest outline can be presented here). England in the eighteenth century was already in large measure a capitalist country, its economy predominantly marketoriented. But this was still an agricultural rather than an industrial capitalism. The

\footnotetext{
${ }^{35}$ Thompson. Customs in Common. 83.

${ }^{36}$ Ibid.. 73.

${ }^{37}$ Ibid.. 85.
} 
urban proletariat was still tiny and retained a traditionalist outlook reflecting its rural origins: the predominantly mercantile bourgeoisie was steadily accumulating wealth. yet its political influence remained slight: the landed gentry was in relative decline as an economic force but still enjoyed virtually untrammeled political supremacy. If we recall Marx and Engels's ironic observations regarding "dominant" ideologies-"we can say, for instance, that during the time that the aristocracy was dominant, the concepts honour, loyalty. etc. Were dominant. during the dominance of the bourgeoisie the concepts of freedom. equality. etc."-it is evident that England during this period must be situated near the end of the first "time" and slightly before the beginning of the second. ${ }^{38}$ In ideological terms. the "patrician/plebs equilibrium" of which Thompson speaks ${ }^{39}$ was constructed within a quasi-medievalist discourse of reciprocal obligations - "the concepts honor, loyalty, etc."-whicl encompassed a patrician variant (the patemalist model) and a plebeian variant (the moral economy). Outside that equilibrium. and in opposition to it, the emergent bourgeois discourse of individual liberties-"the concepts of freedom, equality, etc."-projected its alternative model of political economy as the ideological basis of a counter-hegemonic project. In Thompson's view, that project would not succeed until the $1790 \mathrm{~s}$. when the reactionary climate fostered by the anti-Jacobin wars drove the gentry and the bourgeoisie into each other's arms, and "the reciprocal relation between gentry and plebs ... snapped."to

As regards the historical development of the discourse of reciprocity and the genesis of its patrician and plebeian variants, Thompson's writings appear to display a certain ambivalence. In his original 1971 essay, he seems to assign chronological priority to the aristocratic version. suggesting that the moral economy "was a selective reconstruction of the paternalist [model], taking from it all those features which most favoured the poor and which offered a prospect of

\footnotetext{
${ }^{38}$ Actually, the situation is somewhat more complex than these tems suggest, since England's transition to modenity was. in political and ideological terms, more ambiguous and less decisive llan that of France. As Gramsci notes with respect to the nineteenth century: "In England the development is very different from France. The new social grouping that grew up on the basis of modem industrialism [i. e. , the bourgeoisie] shows a remarkable economic-corporate development but advances only gropingly in the intellectual-political field. There is a very extensive category of organic intellectualsthose. that is. who come into existence on the same industrial terrain as the economic group-but in the higher sphere we find that the old land-owning class preserves its position of vinual monopoly. It loses its economic supremacy but maintains for a long time a politico-intellectual supremacy and is assimilated as 'traditional intellectuals' and as directive [dirigente] group by the new group in power": Gramsci, Selections from Prison Notebooks. 18.

"Thompson. Cirstoms in Common. 95.

${ }^{ \pm} \mathrm{Ibid}$. Even afier this rupture. it should be noted. a rear-guard struggle over the Com Laws was not resolved in favour of the bourgeoisie unti] 1846 .
} 
cheap corn." In the review article published in 1993. on the other hand. we encounter the converse idea that the moral economy may be regarded as an original product of popular culture: "in peasant and in early industrial communities, many 'economic' relations are regulated according to non-monetary norms. These exist as a tissue of customs and usages until they are threatened by monetary rationalisations and are made self-conscious as a "moral economy. $\cdots+2$ The analysis presented in this paper would point to a more subtle, dialectical relationship than either of these formulations seems. at first glance. to admit. It was necessarily the gentry which gave articulate expression to the ruling ideas in pamphlets, in courts of law, in Parliament, in statute books. and so fortl: but in doing so it was only, as Balibar puts it. returning the masses "ovn imaginary ... to them "from above." ${ }^{\cdots 3}$ This being accomplished, the plebs could. of course. "selectively reconstnict" the gentry's version and so forth: what Thompson calls "the dialectical tug-of-war of ideology" $"$ was thus set in motion.

But this "symbolic contest" was simultaneously a material contest. The patricians, for their part, would very likely have been pleased to exert their hegemony through ideological means alone, were such a thing possible: they may well, as Thompson suggests, have preferred to see the paternalist model remain a "platonic ideal." The poor, however, were determined to have their selective reconstruction of that model endowed with a "real existence. ${ }^{-45}$ Thus when the people took to the streets to enforce the very norms of communal reciprocity which the gentry professed to uphold. the latter found "its own" ideology "reechoed so loudly" in the actions and protestations of the crowd "that the authorities were, in some measure. the prisoners of the people. ${ }^{.+6}$ Hence these authorities often gave tacit sanction to the moral economy of the poor. whether by dealing leniently with rioters, or by enforcing legislation against forestalling that might othenvise have remained a dead letter, or by interceding on the people's behalf to induce farmers and merchants to bring their grain to market. And while these immediate returns of popular direct action may not have improved the plebs' overall economic position to any substantial degree. the ever-present "threat of riot," Thompson argues, "would affect the entire marketing situation. not only in years of dearth but also in years of moderate harvest. not only in towns notorious for the susceptibility to riot but also in touns where the authorities wished to preserve a tradition of peace. ${ }^{-17}$ Insofar as this was the case. then, the specific level of the "patrician/plebs equilibrium." as set by the

\footnotetext{
"Thompson. "Moral Economy," 212.

${ }^{42}$ Thompson. "Moral Economy Reviewed." 340.

${ }^{43}$ Balibar. "Non-Contemporaneity," 13, emphasis in original.

"Thompson. Customs in Conmon. 93.

"Thompson. "Moral Economy," 193 and 200.

${ }^{46}$ Pbid.. 189.

${ }^{47}$ Ibid. 239.
} 
"dialectical lug-of-war" we have reviewed, may be said to have determined the price of bread in England during this period, establishing it somewhere "between a soaring 'economic' price in the market, and a traditional 'moral' price set by the crowd. ${ }^{-1 x}$ In more global terms, Thompson contends that popular action reflecting the moral economy. by eliciting the provision of poor relief, charities, subsidies, and so forth. may have improved the plebs' economic position sufficiently to have made the difference between survival and starvation: "If the margin between a poor subsistence and (for groups at risk) famine was small, then marginal redistribution to those in most need may have mattered enough to have shifted a demographic digit. Even between neighbouring towns the different profile of riot/relief might lave influenced mortality. "

In adiancing this interpretation of hegemony and moral economy, I have attempted to counter what appear to me to be certain muddled or misconceived appropriations of Gramsci's and Thompson's work, and thus to refurbish the analytical tool-kit of Marxist historiography. Of course, others may prefer to go on using the instruments with which they are familiar, and may even refuse to be dissuaded from calling a spade a shovel, having gotten along to their satisfaction doing so for years. If Thompson was prepared to admit that he had "no right to patent the term [moral econom!]. ${ }^{.49}$ and if Gramsci had still less of a proprietary interest in hegemon-laving picked up both the term and its definition from the theoreticians of the Third International ${ }^{50}$ - then far be it from me to prohibit Scott or anyone else from assigning whatever meanings they may choose to these words. just as Humpty-Dumpty did in the case of glory. My own "nice, knockdown argument" only claims to have shown that the concepts of hegemony and moral economy. as they were understood by Gramsci and Thompson, are entirely compatible with one another (and with those of Marx and Engels as well); that their meanings are intimately related and complementary rather than mutually exclusive: and that taken together they shed more light on the subtle interpenetrations and co-determinations involved in cultural history than they can do when their fields of application are rigidly segregated. 1 conclude, then, with the well-chosen words of Humpty-Dumpty: "Now, there's glory for you."

\footnotetext{
${ }^{18}$ lbid.. 245 .

"Thompson. "Moral Economy' Reviewed." 340.

S1) See Andersoll. "Antinomies. "
} 